DOI: https://doi.org/10.24127/ajpm.v9i4.3141

\title{
PENGEMBANGAN BAHAN AJAR GEOMETRI BERBASIS SCIENCE TECHNOLOGY ENGINEERING AND MATHEMATICS (STEM) UNTUK MENDUKUNG KEMAMPUAN SPASIAL
}

\author{
Rizky Oktaviana Eko Putri ${ }^{1}$, Feriyanto ${ }^{2}$ \\ ${ }^{1,2}$ Pendidikan Matematika, Universitas Islam Majapahit, Jawa Timur, Indonesia \\ ${ }^{*}$ Corresponding author \\ E-mail: $\quad$ rizky_putri@unim.ac.id ${ }^{1)}$ \\ muhammad.feriyanto@unim.ac.id ${ }^{2)}$
}

Received 05 October 2020; Received in revised form 10 December 2020; Accepted 29 December 2020

\begin{abstract}
Abstrak
Tujuan dari penelitian ini adalah mengembangkan bahan ajar geometri berbasis STEM untuk mahasiswa S1 jurusan pendidikan matematika. Terdapat tiga langkah utama yaitu Fase Pendahuluan, yaitu menganalisis masalah yang dihadapi mahasiswa dalam pembelajaran mata kuliah geometri. Pada tahap ini akan diperoleh permasalahan pokok yang dihadapi dan kebutuhan siswa dalam pembelajaran geometri. Fase Pengembangan merupakan tahap kedua dimana mengembangkan prototipe atau desain awal bahan ajar geometri berbasis materi STEM. Tahap terakhir yaitu Fase Penilaian atau tahap validasi dimana harus menganalisis apakah kualitas produk bahan ajar yang telah disiapkan memenuhi kriteria. Berdasarkan hasil analisis dapat disimpulkan bahwa bahan ajar geometri berbasis STEM layak digunakan dan efektif digunakan dalam pembelajaran untuk mendukung kemampuan spasial mahasiswa. Namun demi tercapainya hasil yang lebih memuaskan maka disarankan untuk membiasakan mahasiswa dalam pembelajaran berbasis STEM.
\end{abstract}

Kata kunci: Geometri; Kemampuan Spasial; STEM.

\begin{abstract}
The aim of this study was developing geometry learning material integrated by STEM principals for undergraduate students in mathematics education program. There were three main steps, Preliminary Research, analyzed the problems faced by students in learning geometry courses. At this stage it will be obtained the main problems encountered and the needs of students in learning geometry. Development Phase was the second step where researchers developed a prototype or the initial design of teaching materials based geometry STEM subjects. The last steps was Assessment Phase or validation phase where researchers should analyze whether the product quality teaching materials that have been prepared meet the criteria. Based on the data analysis can be concluded that STEM integrated geometry learning material is feasible and effective to be used in learning to support students' spatial abilities. However, in order to achieve more satisfying results, it is suggested to familiarize students with STEM-based learning.
\end{abstract}

Keywords: Geometry; Spatial Ability; STEM

This is an open access article under the Creative Commons Attribution 4.0 International License

\section{PENDAHULUAN}

Dunia pendidikan selalu mengalami perubahan seiring dengan perkembangan jaman, tidak terkecuali dengan metode pembelajaran. Perubahan pola pembelajaran ini juga terjadi pada bidang pendidikan matematika. Guru harus selalu berusaha untuk membuat matematika menjadi mata subjek yang menarik dan mudah untuk dipelajari. Sesuai dengan Permen Negara Pendayagunaan Aparatur Negara dan Reformasi Birokrasi nomor 16 tahun 2006, guru mempunyai kewajiban untuk meningkatkan dan mengembangkan kualifikasi akademik 
dan kompetensi secara berkelanjutan sejalan dengan perkembangan ilmu pengetahuan, teknologi, dan seni. Sebagai salah satu universitas di Kota Mojokerto yang menghasilkan calon guru matematika, Universitas Islam Majapahit melalui Fakultas Keguruan dan Ilmu Pendidikan (FKIP) berusaha untuk memberi kesempatan mahasiswa, khususnya mahasiswa prodi pendidikan matematika, agar memperoleh keahlian yang dibutuhkan sebelum terjun ke dunia kerja yaitu di bidang pendidikan dan pengajaran. Kesempatan tersebut dituangkan dalam kegiatan pembelajaran yang dapat mengenalkan mahasiswa pada inovasi pembelajaran serta melatih dan meningkatkan kemampuan mahasiswa pada bidang ilmu matematika yang dipelajari. Salah satu cabang ilmu dalam matematika yang wajib dikuasai oleh mahasiswa calon guru matematika yaitu geometri. Secara garis besar ada tiga kemampuan utama yang harus dimiliki oleh seseorang dalam mempelajari geometri yaitu kemampuan memodelkan, berpikir abstrak dan kemampuan menalar (Goddijn et al., 2014). Namun pada kenyataan selama ini mahasiswa masih kesulitan dalam mempelajari geometri. Berdasarkan hasil observasi diperoleh bahwa mahasiswa kesulitan untuk membayangkan suatu benda dalam benak mereka. Kemampuan dalam menvisualisasikan benda ke dalam pikiran tersebut sering disebut sebagai kemampuan spasial.

Penataan spasial dari sebuah benda dalam menentukan sifatnya atau bentuknya dilakukan dengan mengidentifikasi bagian-bagian spasial dari benda tersebut, menggabungkan bagianbagian benda ke dalam komposit spasial dan membangun hubungan di antara setiap bagian dan setiap komposit dari benda tersebut. (Williams et al., 2010)) memandang kemampuan spasial sebagai penalaran spasial yaitu kemampuan yang melibatkan representasi dan penggunaan objek-objek dan hubungan antar objek dalam kehidupan nyata. Kemampuan spasial seseorang dapat mempengaruhi kemampuan matematika, hal ini ditunjang dengan hasil penelitian yang menunjukkan bahwa kemampuan spasial memiliki hubungan yang positif dengan kemampuan siswa dalam menyelesaikan masalah (Hannafin et al., 2008; Noto et al., 2019; Rabab'h \& Veloo, 2015; Turgut, 2012; Verdine et al., 2014). Berdasarkan hal tersebut maka perlu adanya metode pembelajaran yang dapat mendorong mahasiswa untuk memunculkan tiga kemampuan tersebut selama kegiatan pembelajaran.

STEM adalah salah satu wacana baru dalam bidang pendidikan. Science Technology Engineering and Mathematics (STEM) adalah metode yang menggabungkan empat disiplin ilmu yaitu science, teknologi, teknik, dan matematika sehingga diharapkan dapat menghasilkan pembelajar yang dapat memenuhi kebutuhan abad 21 (English, 2016; Honey et al., 2014). STEM memiliki indikator dari setiap disiplin ilmu tersebut (DES, 2017) yaitu: a) Science, menumbuhkan ketertarikan, pemahaman dari kehidupan, material dan dunia fisik serta menumbuhkan keahlian untuk berkolaborasi, meneliti, dan berpikir kritis. b) Teknologi, melingkupi bidang yang melibatkan aplikasi keilmuan, kehalian dan berpikir komputasi untuk mengembangkan keahlian manusia dan membantu memuaskan keingintahuan manusia pada science. c) Teknik, berhubungan dengan mendesain dan menciptakan produk untuk menyelesaikan permasalahan kehidupan seharihari. d) Matematika, berhubungan 
DOI: https://doi.org/10.24127/ajpm.v9i4.3141

dengan menafsirkan menganalisis, menyederhanakan, menyelesaikan masalah, menilai risiko, membuat keputusan berdasarkan informasi dan lebih memahami dunia di sekitar kita melalui pemodelan masalah secara abstrak dan konkret.

Hasil penelitian menunjukkan bahwa kemampuan guru dalam mengajar berbanding lurus dengan seberapa paham guru tersebut pada bidang STEM (Çevik, 2018; Karisan et al., 2019; Noto et al., 2019). Sehingga perlu bagi calon guru untuk mempelajari dan menerapkan pembelajaran yang berbasis STEM untuk meningkatkan kemampuan dalam menciptakan pembelajaran yang efektif dan menarik (Karisan et al., 2019; Thibaut et al., 2018). Namun pedoman pembelajaran matematika berbasis STEM masih jarang ditemukan khususnya di Indonesia. Dengan fakta yang telah diuraikan, maka dalam penelitian ini akan mengembangkan bahan ajar geometri agar dapat membantu mahasiswa dalam mempelajari geometri dengan berbasis STEM yang mendukung kemampuan spasial mahasiswa.

\section{METODE PENELITIAN}

Jenis penelitian ini adalah penelitian pengembangan dalam bidang pendidikan (Educational Design Research). Subjek pada penelitian ini adalah 18 orang mahasiswa calon guru matematika Fakultas Keguruan dan Ilmu Pendidikan (FKIP) Universitas Islam Majapahit Tahun Akademik 2020/2021 yang telah memogram mata kuliah geometri. Model pengembangan yang digunakan yaitu model dari Plomp \& Nieveen (2010) yang terbagi menjadi tiga fase utama yaitu Studi Pendahuluan (Preliminary Research), Fase Pengembangan (Development Phase) dan Fase Penilaian (Assessment Phase) secara garis besar disajikan pada Gambar1.

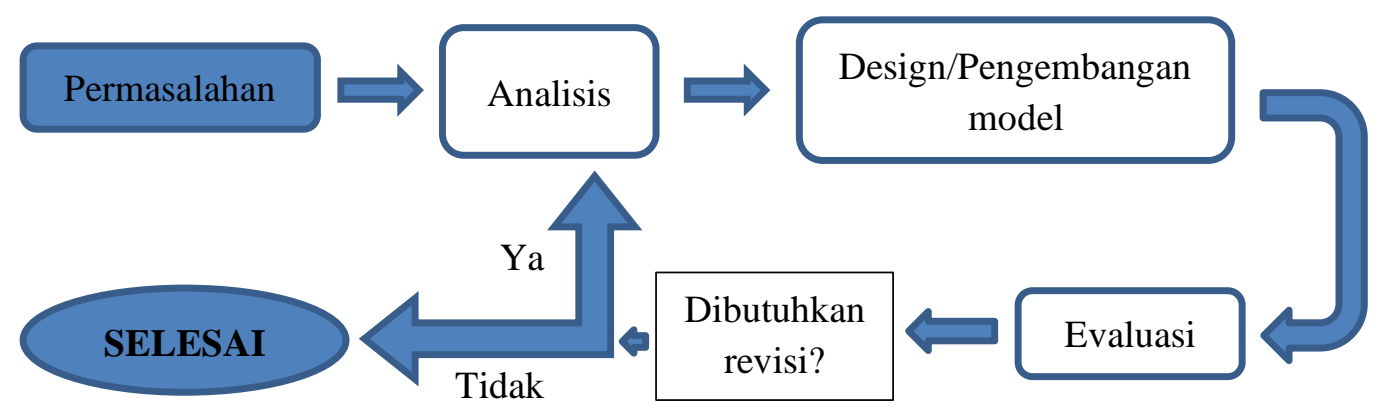

Gambar 1. Alur pengembangan.

\begin{abstract}
Beberapa modifikasi alur pengembangan dilakukan pada penelitian ini didasarkan pada analisis situasi dan kebutuhan. Instrumen digunakan dalam penelitian ini yaitu tes kemampuan spasial dan tes kemampuan matematika dalam hal ini difokuskan pada materi geometri. Tes kemampuan spasial ini digunakan untuk memperoleh data awal subjek penelitian tentang
\end{abstract}

kemampuan spasial. Sedangkan tes kemampuan matematika digunakan untuk memperoleh data kemampuan subjek penelitian pada bidang geometri setelah diterapkan bahan ajar. Data hasil tes kemampuan matematika ini akan digunakan untuk memenuhi kriteria efektivitas pada fase penilaian pengembangan bahan ajar. Terdapat empat tahap pengembangan produk 
DOI: https://doi.org/10.24127/ajpm.v9i4.3141

pada penelitian ini yaitu design proposal, global design, partly detailed product dan completed product. Pengujian produk dilakukan dua kali untuk menguji kevalidan produk yaitu Partly Detailed Product dan completed product. Pada Fase Penilaian digunakan tiga macam kriteria untuk menentukan kevalidan dari bahan ajar geometri yang dikembangkan. Kriteria kevalidan pada penelitian ini menggunakan kriteria evaluasi oleh (Nieveen \& Folmer, 2013) yaitu:

a. Relevancy biasa disebut sebagai validitas isi (content validity) yang diperlukan untuk mengetahui apakah bahan ajar geometri yang telah disusun sesuai dan relevan dengan target subjek penelitian

b. Consistency biasa disebut sebagai validitas penyusunan (Construct Validity) yang diperlukan untuk mengukur apakah bahan ajar yang disusun telah sesuai dengan tujuan dan aspek STEM telah terpenuhi.

Penilaian untuk relevancy dan consistency menggunakan validasi ahli dengan hasil minimal LDP, kriteria penilaian dapat dilihat pada Tabel 1 .

Tabel 1. Kriteria penilaian kevalidan bahan ajar

\begin{tabular}{llc}
\multicolumn{1}{c}{ Simbol } & \multicolumn{1}{c}{ Kriteria } & Keterangan \\
\hline LD & Layak digunakan & nilai $>90$ \\
LDP & Layak digunakan dengan & $75<$ nilai $\leq 90$ \\
& perbaikan & \\
TLD & Tidak layak digunakan & nilai $\leq 75$ \\
\hline
\end{tabular}

c. Effectiveness dibutuhkan untuk menilai keefektifan bahan ajar geometri yang telah disusun pada mahasiwa yang menjadi subjek penelitian. Kriteria efektivitas dari bahan ajar diperoleh dengan memberikan tes kemampuan matematika pada subjek penelitian setelah penerapan bahan ajar dalam kegiatan pembelajaran, if the evaluation focuses on the effectiveness of the intervention, evaluators may decide to assess the performance of learners through a test, a learner report and/or a portfolio (Nieveen \& Folmer, 2013). Bahan ajar dikatakan efektif jika secara klasikal persentase ketuntasan tes kemampuan matematika lebih dari sama dengan $75 \%$. Ketuntasan yang dimaksud dalam hal ini adalah subjek penelitian memperoleh minimal nilai $\mathrm{B}+$ pada tes kemampuan matematika.

\section{HASIL DAN PEMBAHASAN}

Berdasarkan hasil analisis data didapatkan hasil untuk tiap fase pada penelitian ini yaitu, hasil tes kemampuan spasial, untuk Fase Pendahuluan, diperoleh bahwa mayoritas mahasiswa berada pada level sedang hal ini juga berbanding lurus dengan hasil tes kemampuan matematika. Hasil tes kemampuan matematika menunjukkan hasil mahasiswa mengalami kesulitan saat menyelesaikan soal geometri yang diberikan. Hal ini didukung oleh hasil wawancara menunjukkan mahasiswa mengalami kesulitan dalam merepresentasikan objek geometri yang ada pada soal sehingga mempengaruhi hasil tes. Hasil ini sejalan dengan penelitian yang dilakukan yang menyatakan bahwa kemampuan spasial akan mempengaruhi kemampuan dalam merepresentasikan objek-objek geometri dalam benak manusia dan akan mempengaruhi 
DOI: https://doi.org/10.24127/ajpm.v9i4.3141

kemampuan dalam menyelesaikan masalah dalam bidang geometri (Hannafin et al., 2008; Weckbacher \& Okamoto, 2018; Williams et al., 2019). Hasil yang diperoleh pada fase ini juga menunjukkan mahasiswa mengalami kesulitan dalam memahami implementtasi geometri dalam kehidupan seharihari. Pemahaman akan implementasi suatu materi matematika dapat mempermudah mahasiswa dalam mempelajari materi matematika (Yeh \& Chandra, 2015). Hasil pada fase ini akan menjadi dasar pengembangan bahan ajar pada fase berikutnya.

Setelah mengetahui kebutuhan subjek pada selanjutnya dilakukan proses pengembangan modul yang melalui 4 tahap produk sampai mencapai produk akhir. Sesuai dengan hasil yang diperoleh dari fase pendahuluan maka dirumuskan materi yang akan disusun dalam bahan ajar geometri berbasis STEM yaitu kekongruenan, kesejajaran garis, dan kesebangunan. Fase pengembangan menghasilkan empat macam produk yaitu : Design Proposal ini produk yang dihasilkan adalah gambaran umum dari bahan ajar geometri. Gambaran umum ini diperoleh dengan memperhatikan hasil analisis kebutuhan yang telah dilakukan sebelumnya, terutama berhubungan dengan kesulitan mahasiswa dalam mempelajari geometri. Analisis materi juga dilakukan dalam menyusun design proposal yaitu dengan telaah dari literatur yang relevan. Design proposal pada penelitian ini adalah penentuan materi-materi yang diutamakan untuk disusun dalam bahan ajar yang meliputi unsur-unsur dasar geometri, garis-garis sejajar, kongruensi dan kesebangunan segitiga.

Selanjutnya Global Design, sebuah prototip atau model awal dari bahan ajar geometri akan dihasilkan. Model awal ini dapat diwujudkan dalam bentuk penyusunan aspek STEM pada setiap materi. Setelah daftar materi telah tersusun selanjutnya dirumuskan isi dari setiap materi geometri tersebut dengan berpedoman pada aspek STEM dan kemampuan spasial. Aspek STEM dan spasial dalam bahan ajar dituangkan dalam bentuk contoh persoalan seharihari serta kegiatan atau proyek yang dapat dilakukan oleh subjek penelitian secara langsung.

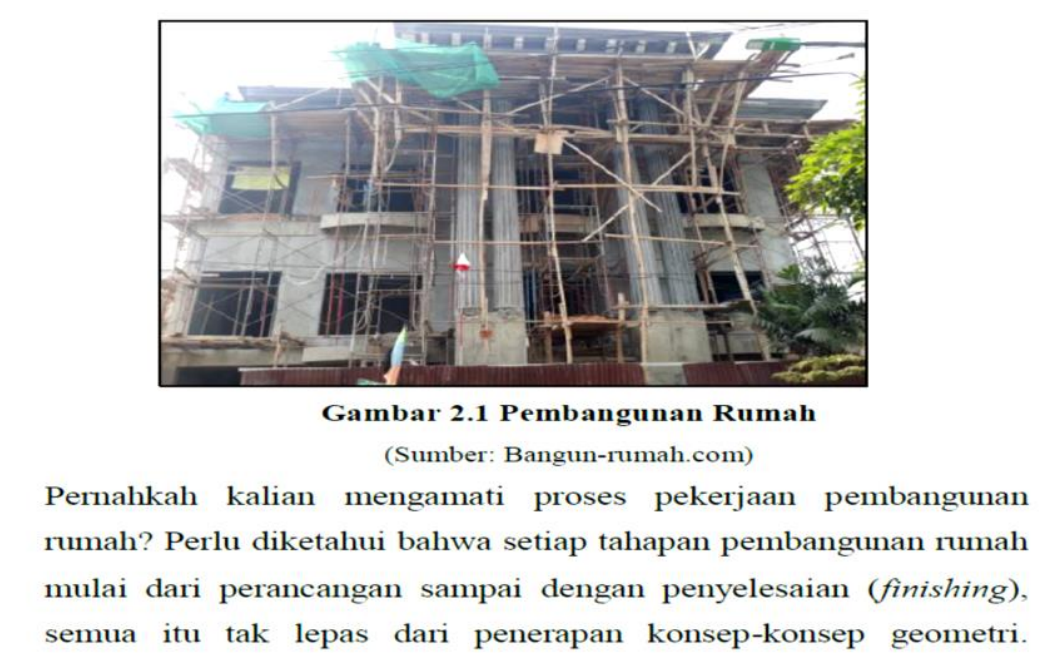

Gambar 1. Contoh aplikasi materi pada bidang Teknik (Enginering) 
DOI: https://doi.org/10.24127/ajpm.v9i4.3141

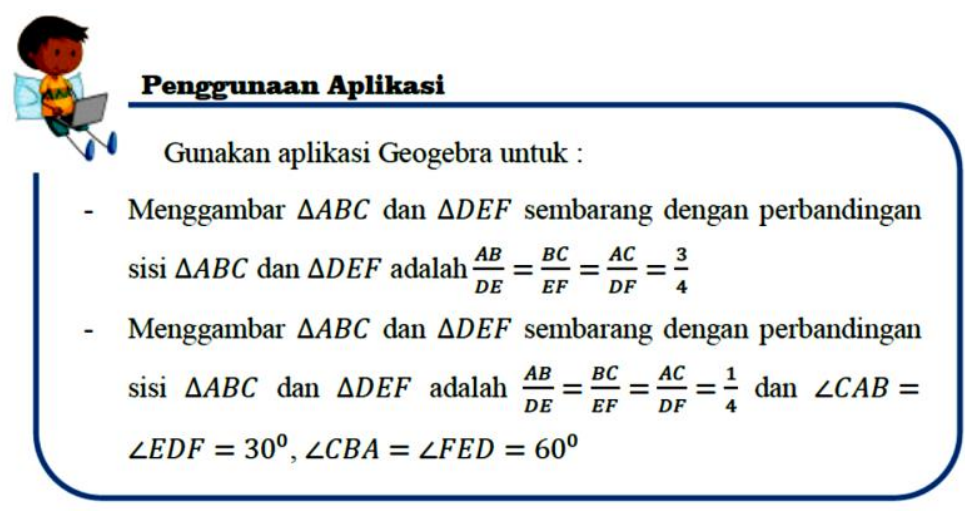

Gambar 2. Contoh penggunaan teknologi

a. Produk selanjutnya adalah Partly Detailed Product, ditentukan sebagian materi untuk dikembangkan menjadi bentuk awal dari bahan ajar geometri. Keseluruhan materi yang telah dirumuskan pada pada tahap global design disusun untuk menjadi produk akhir dari bahan ajar geometri berbasis STEM. Langkah terakhir adalah tahap Completed Product, produk akhir dari bahan ajar geometri berbasis STEM telah terbentuk dan siap untuk di implementasikan pada pembelajaran.

b. Gambar 1 menunjukkan salah satu materi geometri pada bahan ajar yang dihubungkan dengan indikator STEM. Gambar 2 menunjukkan bahwa bahan ajar yang dikembangkan menyisipkan aplikasi geogebra pada materi ini untuk memenuhi indikator teknologi (technology).

Fase terakhir dalam proses pengembangan ini adalah Fase Penilaian. Terdapat tiga macam kriteria penilain pada fase ini yaitu relevancy, consistency dan effectiveness. Kriteria relevancy dan consistency menggunakan teknik validasi dari dua orang validator, Tabel 2 menunjukkan hasil validasi:
Tabel 2. Hasil validasi ahli.

\begin{tabular}{ccl}
\hline Validator & Nilai & \multicolumn{1}{c}{ Keterangan } \\
\hline I & 92 & Layak digunakan \\
\hline II & 88 & $\begin{array}{l}\text { Layak digunakan } \\
\text { dengan perbaikan }\end{array}$ \\
\hline Jumlah & 180 & \\
\hline Rata-rata & 90 & \\
\hline
\end{tabular}

Nilai rata-rata menunjukkan hasil akhir penilaian bahan ajar adalah LDP (Layak Digunakan dengan Perbaikan). Perbaikan yang disarankan oleh validator adalah penambahan contoh aplikasi yang dapat memperkuat aspek STEM pada bahan ajar. Sedangkan kriteria effectiveness diperoleh dari hasil tes kemampuan mahasiswa setelah terlebih dahulu menerapkan bahan ajar pada kegiatan pembelajaran Geometri. Hasil yang yaitu $78 \%$ mahasiswa tuntas dengan nilai minimal $\mathrm{B}+$. Berdasarkan hasil tahap penilaian didapatkan hasil bahwa hasil pengembangan bahan ajar pada penelitian ini yaitu bahan ajar untuk mata kuliah Geometri berbasis STEM untuk mendukung kemampuan spasial mahasiswa memenuhi kriteria effectiveness yang telah ditetapkan. Meskipun hasil tes memenuhi kriteria yang diinginkan namun ada hal yang perlu diperhatikan yaitu mahasiswa perlu diberikan pendampingan dalam pembelajaran karena pembelajaran 
STEM tergolong asing. Hal ini sejalan dengan hasil penelitian Thibaut et al. (2018) yang menyatakan bahwa pembelajaran berbasis STEM perlu dilakukan secara berkala agar tujuan pembelajaran dapat tercapai. Kelebihan dari bahan ajar geometri ini adalah dapat menjadi rujukan bagi mahasiswa calon guru matematika untuk lebih memahami konsep geometri serta aplikasinya pada bidang ilmu lain. Hal ini karena bahan ajar ini disusun berdasarkan aspek STEM. Kelemahan bahan ajar ini adalah keterbatasan waktu dan kurang maksimalnya dalam implementasi produk. Hal ini karena pembatasan ruang interaksi secara fisik yang disebabkan oleh pandemi virus Corona yang terjadi di Indonesia sehingga komunikasi dilakukan secara daring.

\section{KESIMPULAN DAN SARAN}

Berdasarkan hasil dari dua penilaian tersebut maka dapat disimpulkan bahwa setelah melalui proses perbaikan maka bahan ajar geometri berbasis STEM layak dan efektif digunakan dalam pembelajaran untuk mendukung kemampuan spasial mahasiswa. Namun demi tercapainya hasil yang lebih memuaskan maka disarankan untuk membiasakan mahasiswa dalam pembelajaran berbasis STEM. Hasil penelitian ini diharapkan dapat menjadi dasar untuk penelitian selanjutnya untuk menganalisis proses berpikir dan pemahaman mahasiswa melalui pembelajaran berbasis STEM.

\section{DAFTAR PUSTAKA}

Çevik, M. (2018). Investigating STEM Semantics and Perceptions of Engineer Candidates and PreService Teachers: A Mixed Method Study. International Journal of Educational Technology, 5(2), 17.
DES. (2017). STEM Education Policy Statement 2017-2026. Department of Education and Skills. https://www.gov.ie/en/policyinformation/4d40d5-stemeducation-policy/

English, L. D. (2016). STEM education $\mathrm{K}-12$ : Perspectives on integration. International Journal of STEM Education, $3(1), \quad 3$. https://doi.org/10.1186/s40594016-0036-1

Goddijn, A., Kindt, M., \& Wolfgang, R. (2014). Geometry with Applications and Proofs Advanced Geometry for Senior High School, Student Text and Background Information. Sense Publisher.

Hannafin, R. D., Truxaw, M. P., Vermillion, J. R., \& Liu, Y. (2008). Effects of Spatial Ability and Instructional Program on Geometry Achievement. The Journal of Educational Research, 101(3), 148-156. JSTOR.

Honey, M., Pearson, G., \& Schweingruber, H. (2014). STEM Integration in K-12 Education: Tatus, Prospects, and an Agenda for Research. National Academy of Engineering; National Research Council.

Karisan, D., Macalalag, A., \& Johnson, J. (2019). The Effect of Methods Course on Pre-Service Teachers' Awareness and Intentions of Teaching Science, Technology, Engineering, and Mathematics (STEM) Subjects. 15.

Nieveen, N., \& Folmer, E. (2013). Formative evaluation in educational design research. 153, 152-169.

Noto, M. S., Priatna, N., \& Dahlan, J. A. (2019). Mathematical proof: the learning obstacles of pre-service mathematics teachers on transformation geometry. Journal on Mathematics Education, 10(1), 
DOI: https://doi.org/10.24127/ajpm.v9i4.3141

117-126.

https://doi.org/10.22342/jme.10.1. 5379.117-126

Plomp, T., \& Nieveen, N. M. (2010). An introduction to educational design research: Proceedings of the seminar conducted at the East China Normal University, Shanghai (PR China), November 23-26, 2007. http://www.slo.nl/downloads/200 9/Introduction_20to_20education _20design_20research.pdf/downlo $\mathrm{ad}$

Rabab'h, B., \& Veloo, A. (2015). Spatial Visualization as Mediating between Mathematics Learning Strategy and Mathematics Achievement among 8th Grade Students. International Education Studies, $8(5)$. https://doi.org/10.5539/ies.v8n5p1

Thibaut, L., Ceuppens, S., De Loof, H., De Meester, J., Goovaerts, L., Struyf, A., Boeve-de Pauw, J., Dehaene, W., Deprez, J., De Cock, M., Hellinckx, L., Knipprath, H., Langie, G., Struyven, K., Van de Velde, D., Van Petegem, P., \& Depaepe, F. (2018). Integrated STEM Education: A Systematic Review of Instructional Practices in Secondary Education. European Journal of STEM Education, 3(1). https://doi.org/10.20897/ejsteme/8 5525

Turgut, M. (2012). Relationships Among Preservice Primary Mathematics Teachers' Gender, Academic Success And Spatial Ability. International Journal of Instruction, 16.
Verdine, B. N., Golinkoff, R. M., HirshPasek, K., Newcombe, N. S., Filipowicz, A. T., \& Chang, A. (2014). Deconstructing building blocks: Preschoolers' spatial assembly performance relates to early mathematical skills. Child Development, 85(3), 1062-1076. https://doi.org/10.1111/cdev.1216 5

Weckbacher, L. M., \& Okamoto, Y. (2018). Predictability of Visual Processes on Performance in Geometry. Journal of Education and Learning, 7(6), 25. https://doi.org/10.5539/jel.v7n6p2 5

Williams, C. B., Gero, J., Lee, Y., \& Paretti, M. (2010). Exploring Spatial Reasoning Ability and Design Cognition in Undergraduate Engineering Students. Volume 6: 15th Design for Manufacturing and the Lifecycle Conference; 7th Symposium on International Design and Design Education, 669-676.

https://doi.org/10.1115/DETC201 0-28925

Williams, M. E., Graves, L. V., DeJesus, S. Y., Holden, H. M., DeFord, N. E., \& Gilbert, P. E. (2019). Spatial memory ability during middle age may depend on level of spatial similarity. Learning \& Memory, 26(1), 20-23. https://doi.org/10.1101/lm.048280 .118

Yeh, A., \& Chandra, V. (2015). Mathematics, Programming, and STEM. Mathematics Education Research Group of Australasia, 8. 